This item was submitted to Loughborough's Research Repository by the author.

Items in Figshare are protected by copyright, with all rights reserved, unless otherwise indicated.

\title{
"The moving image of eternity": idealism, incompleteness and Ise Jingū
}

\section{PLEASE CITE THE PUBLISHED VERSION}

https://doi.org/10.1353/pew.2018.0074

\section{PUBLISHER}

(c) University of Hawai'i Press

\section{VERSION}

VoR (Version of Record)

\section{PUBLISHER STATEMENT}

This work is made available according to the conditions of the Creative Commons Attribution-NonCommercialNoDerivatives 4.0 International (CC BY-NC-ND 4.0) licence. Full details of this licence are available at: https://creativecommons.org/licenses/by-nc-nd/4.0/

\section{LICENCE}

CC BY-NC-ND 4.0

\section{REPOSITORY RECORD}

Richards, Simon. 2018. "'the Moving Image of Eternity": Idealism, Incompleteness and Ise Jingū". Loughborough University. https://hdl.handle.net/2134/25756. 


\section{PROJECT MUSE}

"The Moving Image of Eternity": Idealism, Incompleteness, and Ise Jing $\bar{u}$

Simon Richards

Philosophy East and West, Volume 68, Number 3, July 2018, pp. 802-825 (Article)

Philosophy East and West

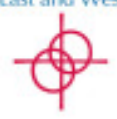

A Quersmily of

Published by University of Hawai'i Press

DOI: https://doi.org/10.1353/pew.2018.0074

$\Rightarrow$ For additional information about this article https://muse.jhu.edu/article/700759 


\section{"THE MOVING IMAGE OF ETERNITY": IDEALISM, INCOMPLETENESS, AND ISE JINGÜ}

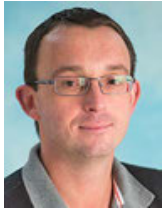

\section{Simon Richards}

School of Architecture, Building and Civil Engineering, University of Loughborough, UK

S.Richards@lboro.ac.uk

\section{Introduction}

Although often shortened to "Ise," Ise Jingū complex in Japan has over one hundred shrines, some represented by a single rock or tree, scattered throughout the cypress forests around Ise city. ${ }^{1}$ The two main shrines, the Naikū and Gekū, represent Japan's finest examples of shikinen sengū, the practice of periodic rebuilding in accordance with Shintō rituals of seasonal renewal and purification, and they have fascinated scholars of aesthetics in Japan and the west. The purpose of this article is to explore the role of Ise in discourses that separate Western and Japanese aesthetics, the former usually characterized as static and "idealist" and the latter as dynamic and "materialist." Acknowledging James Tartaglia's "hypothesis of transcendence," that there are "matters in need of reflection and explanation that are more or less bound to occur to people, irrespective of their cultural and historical background," I shall argue that these aesthetic traditions are fundamentally similar. ${ }^{2}$

We begin with a brief description of the shrines, which date to Emperor Suinin (reigned 29 в.C.E.-70 C.E.) and Emperor Yūryaku (reigned 456-479). The Naikū houses one of the main gods-or kami-of Shintō, the sungoddess Amaterasu, and it was established when Princess Yamato, Suinin's daughter, was tasked with relocating Amaterasu away from the imperial court, where she was believed to be maliciously causing smallpox and influenza epidemics. The Gekū, established later, houses Toyouke, kami of food and harvests. The temples are cypress-wood huts raised on stilts and topped with miscanthus thatch, set in compounds floored with white pebbles. Their aesthetic is simple, reflecting the rice granaries from which they derived. Opulent decoration and materials are used sparingly, limited to incised gold-copper sheets for doors, stairs, and the projecting gable beams and logs (katsuogi) along the roofline. Surrounding the shrines are four fences, with the ordinary pilgrim allowed only beyond the first. The sengū was inaugurated as an official Shintō practice by Emperor Tenmu (reigned 673-86), and barring two intervals (1463-1485 during the Warring States period and 1949-1953 during the post-World War II Allied Occupation), the shrines have been refashioned every twenty years. Also 
refashioned are sixteen other major shrines and sixty-five subsidiary buildings including Treasure Houses and Halls of Offering. But the Naikū and Gekū are not simply dismantled and then rebuilt: new versions are built alongside the old on alternating sites, the goshoden housing the old and the kodenshi receiving the new. Once the new shrines are consecrated, the names of the sites are switched, and for several months the Naikū and Gekū exist side-by-side with their identical yet dilapidated preiterations in a perplexing ontological and semiological limbo.

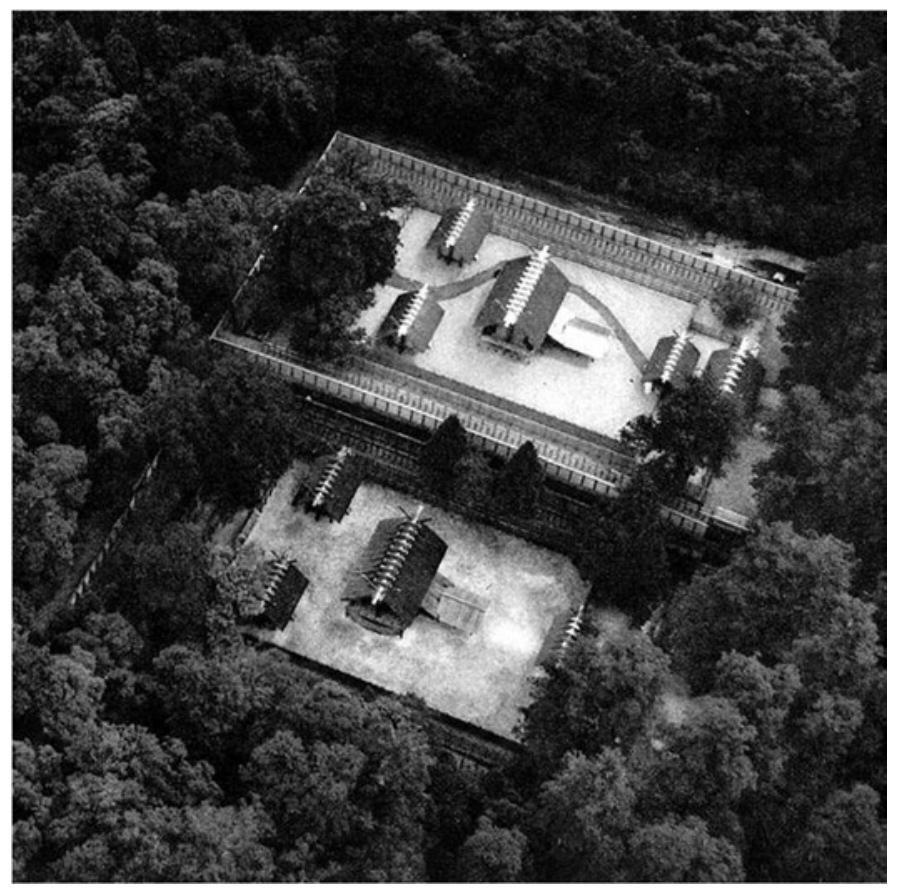

Fig. 1. The impossible view: aerial shot of the old (lower) and new (upper) compounds of the Naiku shrine, including Treasure Houses and Halls of Offering, after the sengū of 1953. The old compound was then dismantled, reverting from goshoden to kodenshi, and left empty save for the hut and shin-no-mihashira that marked the spot of the shrine's return in the next cycle. (Image: Asahi Shimbun, 'Best of News Pictures, 1954')

Finally, the old shrines are dismantled and their materials recycled into souvenir relics and lesser shrines around Japan, or buried in secret sites. The kodenshi then lie empty save for huts in the center of each, which protect the "sacred heart pillar" (shin-no-mihashira) and mark where the shrines must return in the next cycle. ${ }^{3}$ To anyone familiar with the Western assumption that cultural authenticity and value are linked to the preservation of original artifacts, the shrines at this moment offer a startling challenge.

Ise has served Japanese and Western scholars as a focal point around which to debate their differences. Three themes have dominated 
these debates: first, the aspiration toward ideal form; second, the aesthetic of concealment, perishability, and decay; third, the reproduction of culture. More specifically, and when mapped onto assumed regional affiliations, commentators have asked whether Ise might be understood in terms of Western philosophical idealism, of the traditional Japanese aestheticization of incompleteness, or of post-structuralist arguments about the reproducibility and valuelessness of all cultures. The idealist line characterizes idealism as the aspiration to retain perfect forms forever and considers this incompatible with Ise and Japanese aesthetics, a characterization that contributes to the "oppositional paradigm" between Eastern and Western philosophy. ${ }^{4}$ My thesis involves a more nuanced reading that suggests deep affinities with traditional Japanese aesthetics.

There are caveats to be made, however, as scholars of aesthetics often blur the details of different practices and tastes. Michael Marra noted this of Japan after the Meiji Restoration of 1868. Once opened to the west, "the vocabulary of premodern Japanese poetics ... were transformed into aesthetic discourses [that] came to be used to indicate the 'spirit' [of Japan]." Key terms were invented for a culture that historically had no sense or need of them, not only "beauty" (bi) and "aesthetics" (bigaku), for example, but also "art" (geijutsu) and "fine arts" (bijutsu). ${ }^{5}$ The incorporation of Japanese art under Western aesthetics—and idealism, G.W.F. Hegel's variant in particular, was the first to be imported in the 1870s_fuelled arguments that this alienated the Japanese from their traditions and "the reality of difference and diversity." ${ }^{\prime \prime}$ Commentators seem increasingly wary of discussing affinities between aesthetic cultures, sensing here a kind of intellectual colonization. ${ }^{7}$ But it is possible that the resulting segregation relies upon-indeed, may cause-a partial reading of both traditions. If the literary philosopher Karatani Kōjin, a fierce critic of the imposition of Western aesthetics, can advocate "bracketing" irreconcilables in order to explore common ground, then this is perhaps not merely a symptom of "hegemonic western visual culture." ${ }^{8}$

This article has two sections, divided thematically.

The first is themed to modernist architecture and traditional Japanese aesthetics. It explores how Ise was discussed among architects, who presented it as an amalgam of Japanese tradition, proto-modernist abstraction, and idealism, which was questioned in a later post-structuralist reading. Ambiguities in this reading are used to reconsider a materialist-idealist dialectic as a bridge between aesthetic cultures, and the section ends by reading similar ambiguities back into traditional Japanese aesthetics.

The second section is themed to classical idealism, its contested interpretations, and its uptake and interrogation in Japan. It begins with recent accounts of Ise, which reinforce the argument that idealism is inimical to Japanese aesthetics, before exploring more dynamic interpretations of idealism and the affinities these imply. It is argued that the most 
strenuous attempts to segregate these aesthetics often reveal more in common than perhaps intended.

\section{"The Refinement of the Transitory": Modernist Architecture and Traditional Japanese Aesthetics}

\section{Ise and modernism: Taut, Tange, and Kawazoe}

Ise did not always play a role in discussions of aesthetics. For most of its history, it served the Japanese primarily as a site of imperial identification, pilgrimage, and tourism. After the 1868 Restoration, foreign visitors dismissed the buildings as miserable huts and were enraptured by the grandeur and expressiveness of shoggun mausolea, reflecting the decorative bias of late-Victorian taste. But the German architect Bruno Taut wrote and lectured in Japan from 1933 until 1936, and Ise caught his eye. The finest architecture, for Taut, eliminated decoration to focus on simple geometric shapes, often making a display of its own construction. In Houses and People of Japan (1937), Taut described the shrines as "extremely simple, even plain, but it is an intended refinement of the wholly reasonable." In other words, it was the perfect expression of function. Here "The art of omission is pushed to the extreme... [for] an architectural purity achieved by simplicity that cannot be surpassed and does not exist anywhere else in the world, not even in Japan." But as well as being "uniquely" Japaneseparticularly for the sengū that "ever renews itself like eternal living nature [for] the refinement of the transitory" -Taut also presented Ise in relation to modernist architecture: he discerned in the simple lines and expression of function an aesthetic that prefigured and justified the best of what was increasingly to be found in Europe, in the buildings of Le Corbusier, Gerrit Rietveld, Walter Gropius, and indeed himself. ${ }^{9}$

As Jonathan Reynolds has demonstrated, this "modernist construction" of an aesthetic around Ise was reenergized in the 1960s by the architect Tange Kenzō and journalist Kawazoe Noburō. They subjected Ise Shrine-which had become tainted due to its spiritual legitimization of Japanese imperial expansion-to "rehabilitation [that] neutralized" these associations, such that "aspects of the shrines' history could be utilized to promote new cultural practises." Ise was again recruited to publicize contemporary architecture, in this case the "Metabolist" movement. Launched at the World Design Conference in Tokyo in 1960, Metabolism combined the clean, elegant aesthetic of 1920s-30s modernism, the heavy massing, and rough-cast concrete of its post-WWII "Brutalist" phase, with a brand-new processoriented rather than goal-oriented design approach that prioritized indeterminacy and flexibility. Metabolist buildings and cities would change, grow, and adapt in ways analogous-metaphorically, at least-to metabolic processes. The Ise shrines, with their clean lines, bold shapes, natural materials and textures, and dynamic life and death, were seen as prefiguring all this. This was the agenda underlying the jointly authored book, Ise: Prototype of 
Japanese Architecture (1962), in which Tange and Kawazoe were aided by the cunningly composed and cropped photographs of Watanabe Yoshio, which emphasized the abstract proto-modernist qualities of the shrines, as well as by the book design of Nippon Design Center Inc., representing nowclassic 1960s modernist chic. ${ }^{10}$

For their interpretation, Tange and Kawazoe deferred also to Fukuyama Toshio, who in the 1930s and '40s had published widely on Japanese antiquities including his own archaeological work on the raised storehouse building type used for the shrines. Through Fukuyama they acknowledged that Ise borrowed decorative motifs from China and also that the raised storehouse was an import to Japan from other Pacific island cultures; yet both agreed with Fukuyama that there was something quintessentially Japanese about the sengu and something formally pure about the designs as well. The rebuilds were an attempt to preserve or rediscover this. Remove the imported decoration and there was "quintessential form, behind the tangible shapes," according to Tange. Kawazoe agreed that, despite some variation over the years, "the architectural style of the principal buildings ... was almost the same as it is today." And of course they stressed the modernity of Ise, with Kawazoe admiring its "structural beauty, known as the 'Mondrian pattern,' which relies on interplay of horizontals and verticals." ${ }^{\prime 11}$

The aesthetic behind Piet Mondrian's sparse, rectilinear canvasses was explained in his essay "Plastic Art and Pure Plastic Art" (1934), which detailed the struggle between dual tendencies in human nature. Subjectivity (manifested in emotional, figurative, and narrative art) fought objectivity (manifested in abstract art), but the "evolutionary" triumph of the latter was imminent. All art would soon commit to "representing reality objectively" and to "universal beauty." This aesthetic, which aspired paradoxically to encapsulate in visual form a transcendental reality that lay beyond the grasp of the senses, was derived from The Republic of Plato, and so too was the sense of struggle against the limitations of our animal nature: "time is a process of intensification . . . toward the essence of things and of ourselves ... Our human capacities do not allow of a perfectly objective view, but that does not imply that the plastic expression of art is based on subjective expression."12 Another key influence on Tange and Kawazoe was Le Corbusier, the best-known European architect in the world at this time, who synthesized an idealist aesthetic from various sources. ${ }^{13}$ In sum, Tange and Kawazoe presented the sengū and shrines as truly Japanese, while their formal simplicity and "plain, unadorned surface[s]" ostensibly aligned them with certain idealist strands of $20^{\text {th }}$ century abstraction as well. ${ }^{14}$ This interpretation was soon to be challenged.

Ise under wraps: Isozaki, Barthes, and Sakabe

The foremost Japanese advocate of the post-structuralist interpretation of Ise is the architect Isozaki Arata, an associate of the "Tange Lab" at Tokyo 
University during the time Tange and Kawazoe were recruiting Ise to their cause. Isozaki however was suspicious of Metabolism, and from the 1970s onward his work - both written and built-became increasingly provocative. The smashed and sunken public plaza of his Tsukuba Center (1983), for example, a seemingly earthquake-stricken inversion of Michelangelo's $16^{\text {th }}$ century Piazza del Campidoglio in Rome, was contemporary with the efforts of Bernard Tschumi, Peter Eisenman, and Jacques Derrida to "deconstruct" the conventions of a public park with La Villette in Paris. But before looking into Isozaki's thoughts on Ise, we should consider his influences: the philosophers Roland Barthes and Sakabe Megumi.

Empire of Signs (1970), a philosophical memoir of a visit in 1966, found Barthes scouring Japan for evidence of his thesis that culture offers no stable foundation of truth or value, and his examples were legion. ${ }^{15}$ The most important for us are his remarks on haiku and on Japanese packaging. Haiku seem to allude to profundity within their brief and often mundane three lines, but they are merely brief and mundane: "the haiku's flash illumines, reveals nothing; it is the flash of a photograph one takes very carefully ... but having neglected to load the camera with film." Their significance lies only in mirroring the tropes of other haiku but "the mirror is empty," thus they are recited "twice, in echo ... [to underline] the nullity of meaning."16 Barthes saw this everywhere in Japan, but especially in the Japanese love for elaborate, multilayered product packaging:

[Packaging] postpones the discovery of the object it contains - one which is often insignificant, for it is precisely a specialty of the Japanese that the triviality of the thing be disproportionate to the luxury of the envelope ... Thus the box acts the sign: an envelope, screen, mask, it is worth what it conceals, protects, and yet designates ... but the very thing it encloses and signifies is for a very long time put off until later, as if the package's function were not to protect in space but to postpone in time; it is in the envelope that the labor of the confection (of the making) seems to be invested, but thereby the object loses its existence, becomes a mirage: from envelope to envelope, the signified flees, and when you finally have it (there is always a little something in the package), it appears insignificant, laughable, vile. ${ }^{17}$

Barthes seemed unaware of Ise, although we can imagine what his reading might have been: packaged seductively in ritual and fences to be unwrapped at the tantalizingly postponed twentieth year, the meaning dodges away; one gift-the kodenshi-exposed empty and trivial, the hoped-for spiritual content of the other-the goshoden-wrapped up and hidden again; two sites side-by-side equivalent to the haiku recited twice to underline the emptiness. All that can be admired is the fresh new packaging. And so "what is begun by one is continued by the next, without interval." 18 

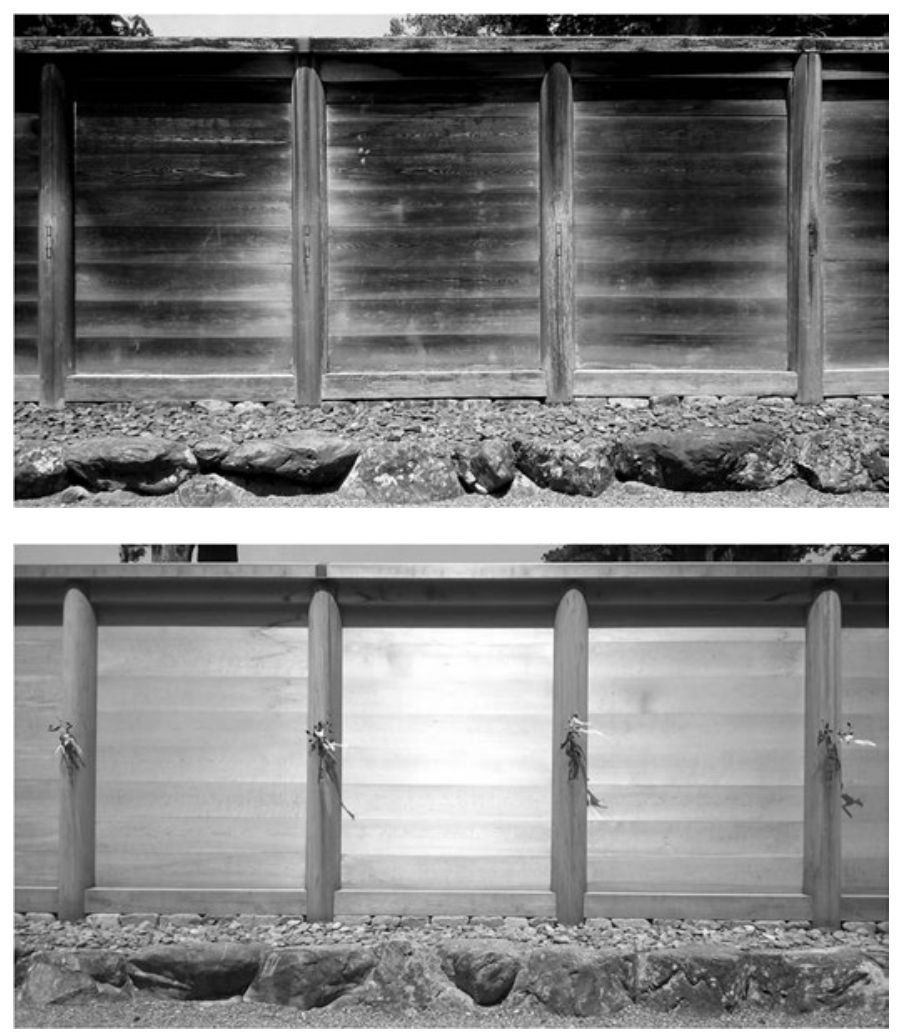

Figs. 2 and 3. The real view: admiring the 'packaging'. Comparison of old and new outer fences of the Geku shrine in April 2014. Apart from glimpses of roofline ornamentation, the ordinary pilgrim will not see much more of the shrines than this. (Images and copyright owned by author)

These readings were echoed in the 1980s by Sakabe Megumi, professor of aesthetics at the University of Tokyo, who interrogated the indigenous language Yamato to expose the emptiness of Japanese aesthetic culture. ${ }^{19}$ Sakabe poked at terminological ambiguities in Nō masked drama, which attained its highest form under the practitioner-theorist Zeami Motokiyo in the $14^{\text {th }}$ and $15^{\text {th }}$ centuries, to diagnose meaninglessness: "In the original language . . . there is only one word to indicate mask as well as (the natural) face, 'omote.'" Sakabe contrasted omote with the Latin "persona," which denoted not only mask but also "the notion of individual and autonomous 'person'" behind it. Recalling Barthes' reprehensible physiognomic diagnosis of the depthlessness of Japanese culture from the facial features of Japanese people, Sakabe's omote was a depthless surface behind which lies nothing. In Japan generally, he concluded, words never point to "substantial beings," concepts, objects, or even "some ideal entity (as in the case of Platonism)" that might lie behind. ${ }^{20}$ Sakabe noted also that the Japanese word for imitation (modoki) implied something "poorly done... false, counterfeit," 
of meaning annihilated "through doubling, mockery," and he aligned this with Barthesian "text" where "nothing exists" but "surfaces," "reflections," "changes," "metamorphoses." 21

Isozaki worked these ideas into Japan-ness in Architecture (2006). Prints, novels, and tourist literature showed that the Ise shrine buildings and precincts had changed over time, yet the myth persisted that there was no "deviation . . . in the repetition," that "The beginning form is simply traced by a re-enactment." Ise was "significantly redesigned at crucial junctures," then, although "a certain will to readjust the design toward a perceived authentic form ... [and] recapture the 'pure' form, or archetype . . . must constantly have been at work." Even so, this was not "an original form," but merely a "mirage-like . . nonexistent origin [that] is always veiled in gesture." The origins of Ise were fiction, sustained by the charade of the sengü:

Something essential is veiled, or so we feel. When you visit Ise, you experience the true object as blocked and invisible... At the headwater of Ise's seduction, we encounter the self-veiling mechanism... an obscuring mechanism... whose origin itself must be somehow fabricated, for there is no origin as such. Insinuation that an origin exists has sustained the seduction. What is seen deep in the cedar forest is a swindle - or veiling ... what we have to do is pay attention to the rhetoric of veiling employed in this fabrication of origin - the only "real" truth at Ise. ${ }^{22}$

This veiling "mechanism" included also the fences that block access and views. Isozaki concluded that there is no more substance to Ise than the ritual of renaming, equivalent to the $\bar{O}$-name-sai ceremony of succession when the imperial spirit enters a new body. ${ }^{23}$

And yet Isozaki remained ambivalent. Shintō shrines may be little more than small enclosures marked off with string, but "these minimal acts - siting and demarcation - suffice." They correspond with the elusive sense of transcendence associated with Shintō divinities:

This notion of kami is not anything solid or constant, but was originally an invisible presence invited from somewhere. The objective locus of festival and ritual is just a device for their advent. Thus the kami never manifests itself and can easily depart. The place to invite such kami may be essentially void - a "central nothing." Being void, it can also absorb. ${ }^{24}$

Thus the empty sites of the kodenshi are more vibrant with potential meaning than the goshoden alongside them. ${ }^{25}$ This reinforced earlier readings of Ise by Tange. There was no direct figuration of the Shintō kami, Tange observed, but instead an aspirational gesture: the clearing away and demarcation of spaces and objects, for example, through rice-straw ropes (shimenawa) or rock arrangements (iwasaka), into which it was hoped a kami might enter. "Instead of thinking in terms of images of the deities," Tange observed, "man thought in terms of an image of the space in which the deities moved, and proceeded in various ways to symbolize this space." ${ }^{26}$ 
Scholars have discussed this in relation to the Zen Buddhist concept of $k \bar{u}$, denoting stillness, silence, and void before the hoped-for moment of enlightenment, and madori, the nearest equivalent for Western architectural "design," where ma suggests "interval" or "between-ness" in both temporal and spatial senses while dori suggests the "grasping" of this. Together they implicate design as the creation of ambiguous time-spaces held in expectant tension. ${ }^{27}$ Isozaki curated an exhibition around this concept. "Ma: SpaceTime in Japan," which opened in Paris in 1978, presented traditional examples of this aesthetic of ambiguity and anticipation, including the aimless stroll spaces of Japanese gardens, those moments of stillness and quiet in Nō known as "non-action" (senu tokoro), sumie painting where the ink-wash line floats in empty white space, as well as architectural elements such as shöji and fusuma that serve as indeterminate windows, doors, and walls. As well as adopting a post-structuralist line on Ise, then, where veiling, impermanence, and the sengū represent a charade intended to conceal meaninglessness, Isozaki suggested contrarily that the same qualities represent the anticipation of meaning and even transcendence. And he combined this intriguingly with Tange's idealism when remarking that the sengū sought "to preserve identity through maintenance of an archetypal form." ${ }^{28}$

Ambiguities in traditional aesthetics: Saitō, Norinaga, and Kenkō Isozaki's alternative interpretation ties into a strand of traditional Japanese aesthetics involving the celebration of artifacts and experiences that are concealed or fragmentary, including buildings that fall into dilapidation then to be rebuilt. The philosopher Saitō Yuriko has explored this across a wide range of Japanese arts and life practices. She discusses the Heian-era aristocratic sentiment of mono no aware ("the pathos of things"), encapsulated in literature such as Sei Shōnagon's The Pillow Book and Murasaki Shikibu's The Tale of Genji (both ca. 1000), with their wistfulness at loss and the passage of time, and Buddhist monk Yoshida Kenkō's Essays in Idleness (ca. 1330), which celebrated motifs such as the moon behind clouds and falling cherry blossoms as well as chipped utensils, frayed scrolls, and incomplete collections. These sentiments fed the $16^{\text {th }}$ century wabi-sabi aesthetic of dilapidation and decay epitomized by tea master Sen-no-Rikyū, who advocated meticulous care in the design and equipage of tea houses to make them appear as ramshackle peasant huts. Saitō's examples are comprehensive, even including - in a pointed reversal of Barthes-the delayed gratification of multiple layers of gift packaging. All these suggest "the celebration of those qualities commonly regarded as falling short of, or deteriorating from, the optimal condition of the object." But these were not only celebrated merely as a symbol of the transience of life and the inevitability of material decay and disappointment, but also for what they imply of the truly satisfying experience that is tantalizingly imminent yet just out of reach: 
the appreciation of the imperfect was not merely directed towards the sensory qualities such as asymmetry, irregularity or obscurity, or their contrast with the opposite qualities. These qualities are aesthetically appreciable precisely because their opposites are possible to achieve... the positive aesthetic experience of concealment and obscurity presupposes a premise that the object of quest will be available to us sooner or later. ${ }^{29}$

Saitō's interpretation invokes the literary theorist Motoori Norinaga, an advocate of the pro-Shintō kokukagu ("nativism") school of thought in the late $18^{\text {th }}$ century. Norinaga was fiercely critical of the popular definition of mono no aware as melancholy over the impermanence of material phenomena and earthly life. Although there are more melancholy than joyful poems in the canonical anthologies of the Heian era this did not mean that people harbored a "hope for being lonesome and sad." Such an interpretation, when combined with the celebration of the transiency of one's own life, was a "violation of . . general human desire ... carried over from foreign customs." Norinaga turned this into a thumping attack on Kenkō and advocated instead an aesthetic that aspired toward clarity, perfection, and order, which he presented as closest to native Japanese taste and broader human nature. ${ }^{30}$ He developed this through a painstaking etymological analysis of the word aware in Heian poetry, which concluded: first, that aware was a broad empathetic response that might be uttered in response to anything, including delight, surprise, laughter, lust, contempt, fury, disgust, or intrigue, meaning that "the definition of aware as the heart's movement because of a specific feeling (sorrow) is derivative"; second, that aware represented a search for the stable and transcendent truths contained within the Yamato language and uttered originally by the Shintō kami. ${ }^{31}$

Despite Norinaga's quarrel with Kenkō, their aesthetics were not dissimilar. It is true that Kenkō made mournful statements about bodily decline and death, wondering "What pleasure is to be found while we await them?" But he did not, as Norinaga alleged, advocate the aesthetic celebration of decay, transience, and sadness as ends in themselves. On the contrary, while "It is the ephemeral nature of things that makes them wonderful," this is because they encourage one to "taste life to the full." Whenever Kenkō mentions the pleasure of things and situations that are imperfect, concealed, or unattainable, it is clear that the pleasure derives from the memory of a time when they were perfect, revealed, and attained, and the anticipation of a time when they might be so again. The melancholy of year's end and the onset of winter is enlivening, as "watching the new year dawn in the sky, you are stirred by a sense of utter newness, although the sky looks no different from yesterday's." And it is the same with less than perfect buildings, furnishings, and fabrics: "Something left not quite finished is very appealing, a gesture toward the future." ${ }^{32}$ 
Norinaga and Kenkō presented dilapidation and decay, longing and melancholy as moments in a broader aesthetic experience that yearns for the ideal, but others disagreed. The $20^{\text {th }}$ century philosopher Ōnishi Yoshinori, for example, asserted that aware denoted misery, decay, and "world-weariness," an aesthetic "developed completely among our own people ... that is completely alien to the West." Although Norinaga argued the opposite, Ōnishi contended that he did not know his own mind and was in agreement unconsciously. ${ }^{33}$ Western commentators have also fixated on the aesthetic of impermanence and its uniqueness to Japan. Aware might be taken for melancholy, sabi for the ramshackle and rusted, yuggen for the hidden mysteries of $N \bar{o}$, and ukiyo for transient, illicit night-pleasures, even while it is admitted that much of this feels like "hackneyed imagery." ${ }^{34}$ "Generalizations are always risky," Donald Keene warned, before doing the same. ${ }^{35}$ While melancholy and impermanence certainly appear in Western art, they are alleged to be unwelcome there, whereas in Japan they represent "a special penchant for finding beauty in such incessant change." ${ }^{36}$

We can begin to unite these strands by recalling Isozaki's ambiguous interpretation of Ise. The orchestration of the sengū and the concealment of the shrines exemplified post-structuralist ideas on the emptiness and fraud of culture, he said. But they also exemplified traditional Japanese aesthetics where impermanence and emptiness implied not only melancholy enjoyed for its own sake but also a striving for the ideal, as Saitō, Norinaga, and Kenkō confirmed. And this was echoed in the Metabolists' characterization of Ise as changeable yet also eternal. These interpretations seem to point toward a united aesthetic but, in the main, the critical and philosophical discourse sidelines idealism or derides it as a Western imposition. The next section confirms this bias with some recent debates about Ise before challenging it on the basis of a less doctrinaire interpretation of idealism.

\section{"The Completeness of Incompleteness": Contested Interpretations of Classical Idealism and Its Uptake in Japan}

\section{"Plato was not Japanese"?}

The buildup to any sengū always inspires scholars to interrogate Ise afresh, and the latest was no exception.

Dominic Mclver Lopes investigated Ise through contradictory "Old" and "Young" propositions: "( $\mathrm{O})$ Ise Jingu is more than one thousand years old. (Y) Ise Jingu is no more than twenty years old." The "standard ontology" of architecture, favoring proposition $\mathrm{Y}$, links authenticity to the enduring materiality of a building: "no building survives the simultaneous replacement of all its parts." But at Ise, the new shrines are considered authentic originals. Lopes explained this by emphasizing its temporal over its material aspects: Ise should be considered a performative work similar to music. ${ }^{37}$ Rafael De Clercq responded that Lopes' thesis "must look strange even to 
the Japanese." For De Clercq, the standard ontology $(\mathrm{O})$ sufficed when one acknowledged that "a different building [can] be supposed to be the Ise Jingū at different times in history." Successive presidents become the president through the transfer of authority into a different person, he noted, which recalls Isozaki's remarks on the imperial $\bar{O}$-name-sai ceremony. The situation is identical at Ise, where ritual marks the transfer of sacred authority into a new shrine. ${ }^{38}$

Jeffrey Perl considered Japan a copying culture. Japanese collectors of ukiyo-e, for example, admire reprints from recarved woodblocks more than first prints off the original. Reprints "are not thought of as facsimiles, in the Western derogatory sense; they are originals of a fresh edition of an old, well-loved design." Here and at Ise, "Japanese ontology... as Roland Barthes explained... differs radically" from the west, which favored "architectural, as well as ontological, foundationalism ... ideals of solidity [and] permanence." "Plato was not Japanese," Perl decided. ${ }^{39}$ Wayne Anderson responded by agreeing, and aligning the sengū with Barthes' notion of creativity as "substitution and nomination," which results not in worthless copies but in "sustained originality." Questions of authenticity are "so intricate and unclear ... [that] we may as well decide" through arbitrary naming "as if the object existed." A linguistic convention equivalent to the "moving constant" of kingship was held for the transferral of authenticity in woodblock prints, the shrines at Ise, and the multiple-edition bronzes of Auguste Rodin. ${ }^{40}$

This was a reference to the quarrel between art critic Rosalind Krauss and curator Albert Elsen over the "Rodin Rediscovered" exhibition in the early 1980s. Krauss had presented Rodin's casting practices in terms of the post-structuralist condition of reproductions-without-originals, while Elsen defended Rodin in terms of the conventional market practice whereby authorial sanction of a reproduced piece made it authentic. ${ }^{41}$ These recent discussions of Ise cover the same ground: endless reproduction offset with legitimacy granted through linguistic convention. The "opposing" arguments blur together, unsurprisingly, as all are contained within post-structuralist horizons. They consider movement, change, repetition, and decay-at Ise and in Japanese aesthetics generally - to be incompatible with the search for perfection and permanence in Western architecture and idealist aesthetics; a position encapsulated in the vacuous truth that "Plato was not Japanese." For the remainder of this section, we reconsider the affinities between these aesthetic cultures explicitly from the Western idealist side. We also consider how attempts to segregate aesthetic cultures often have the contrary effect of exposing common ground.

\section{Dynamic Idealism: Plato}

A discussion of authenticity in architectural restoration distinguished between the "Platonic" approach, which favored preserving the perfected appearance of a building, and the "Historical," which acknowledged the passage of time, 
including degradation, patching-up, alterations, and rebuilds. ${ }^{42}$ It is a similar binary formula that has led to the segregation of Western from Japanese aesthetics in discussions around Ise. As the writings of Tange and Isozaki, Kenkō, and Norinaga seem to hint, however, these alternatives are not binding: Japanese temporality and materialism do not exclude the ideal, and perhaps Platonic idealism does not exclude time and matter.

We must acknowledge, however, that there is an established tendency to limit and undermine idealism. This dates to the materialist bias of the emerging analytic tradition in the early $20^{\text {th }}$ century, notably G. E. Moore's "The Refutation of Idealism" (1903), where he argued against George Berkeley's $18^{\text {th }}$ century thesis of "esse est percepi" - that reality lies only in the mind of the perceiving subject-in favor of the independent existence of a material world outside the consciousness that perceives it. ${ }^{43} \mathrm{M}$. F. Burnyeat's "Idealism and Greek Philosophy" (1982) pushed this further to argue that idealism emerged from the misinterpretation of ancient materialist philosophy. ${ }^{44}$ But this characterization of idealism is a straw man, set up to be knocked down from the pro-materialist standpoint. A recent book argues that the "ferocious oversimplifications" of Moore, which equated idealism with "the position that reality is mind-dependent," represented "a poor view of Platonism" in particular and an "impoverished understanding of idealism" in general. This has built nonetheless into an influential discourse as well as an orthodoxy in philosophical education that "has proved extraordinarily resilient to correction." In their exploration of the idealist-materialist dialectic in Plato and other idealist and indeed materialist thinkers, the authors argue that "The world of change, birth and decay is not a world causally isolated from that of the Ideas." The idea is "the cause of the approximations of becomings to particular forms" and is therefore "inseparable from its moments" of partial realization in the material world over time, which ceaselessly "generates and decays." ${ }^{45}$ Earlier philosophers, including Gustavus Zerffi, C. M. Bakewell, and Gustav Mueller, made similar points. They agreed on the partial realization of ideas in the world; that a particular idea assumes a "dynamic, moving function [that] unfolds itself" in matter which decays and precipitates its own "critical negation"; on the wrongheaded separation of idealism and materialism as a result of philosophical partisanship; and on the fundamental affinity of materialism and idealism as "twin brothers under the skin," with "their differences consisting only in their starting-points." 46

These arguments, although focusing on epistemology and ontology, resonate with Plato's idealist aesthetics. The Republic is indeed faithful to "pure" idealism, as art was characterized there as a materialist debasement of pure thought. ${ }^{47}$ In The Symposium, however, ostensibly a dialogue among men discussing love, is Plato's more nuanced theory of art. Socrates-Plato's avatar-argues that attraction to a lover begins on a sensual, physical level. But after the early passions, the relationship should 
turn to the qualities of mind and spirit, it becoming then the elder partner's duty to improve his lover through lessons on virtue, character, and comportment, and to remake him into an ever more perfect realization of that archetype of himself that exists in a higher reality. The lover represents the artwork and he will partake of something of the eternal in an aspirational process that must nonetheless fail, the corruptibility of his body and mind compromising it over time. The impossibility of attaining the ideal is dramatized through the main authority in The Symposium, the Prophetess Diotima. Even she appeared never to have apprehended fully the archetype of beauty: "So what should we imagine it would be like,' she said, 'if someone could see beauty itself, absolute, pure, unmixed, not cluttered up with human flesh and colours and a great mass of mortal rubbish, but if he could catch sight of divine beauty itself, in its single form? Do you think ... that would be a poor life for a human being ...? ?" Plato characterized "Love" and art not with perfect attainment and fulfillment but with frustration, corruption, and failure; yet as the offspring of "Resource and Poverty," they aspire continuously and try again. ${ }^{48}$ The dynamic is similar in the Phaedrus and Phaedo, in which Socrates describes the soul's aspiration to return to heaven. But the soul upon death "can never get clean away to the unseen world [as it] is always saturated with the body ... [and] falls back again into another body, where it takes root and grows." ${ }^{49}$ Life and death are experienced, in these dialogues, as an ongoing cycle of reinventions as a person feels not only the corrupting pull of the sensual, material world but also strives to respond appropriately to the ideals that are realized there in partial and imperfect forms.

This dynamic idealism has been noted by others. Phillip Sherrard explored how Plato's ideals were not "trans-temporal" or "static" but discovered in the world according to the outlooks and skills of the people who fashioned them. ${ }^{50}$ Omid Tofighian interpreted the Timaeus to mean that humans require their art in human terms: "representations of divine entities . . . are only beneficial if they themselves are 'anti-divine,' meaning that they must necessarily negate themselves." The ideal is experienced as "coming to be and ceasing to be," in the words of Timaeus, "but never fully real." Identifying a "copy structure" within Platonic idealism, Tofighian argued that each copy is a "disposable vehicle" and "worthless in-itself" but points to something beyond. ${ }^{51}$ Mueller had also described artistic creation in Plato as a "re-creative or imitative dialectic." Idealist creation involves the repetition of something that paradoxically remains unique, of something located precisely in time that remains timeless: "the one is the other; it is one and being, hence two, hence many; the one is a member of a series ... The one as temporal is older and younger than and simultaneous with itself." ${ }^{152}$

The philosophers discussed here presented dynamic idealism as intimately related with materialism and even with the Epicureans. ${ }^{53}$ This 
relationship was based on shared themes of incompleteness, decay, repetition, and aspiration, precisely the themes that many have used to describe traditional Japanese aesthetics.

\section{Idealism Contested: Shōyō, Kusanagi, and Schopenhauer}

Just as philosophers distanced materialism from idealism, so too they have distanced Japanese aesthetics from idealism, but this has caused a conceptual rigidifying of both aesthetic traditions. The Japanese encounter with Western aesthetics was dominated initially by idealism, largely through the American philosopher and art historian Ernest Fenollosa, who joined Tokyo Imperial University in 1878. Fenollosa lectured to the general public, academics, and learned societies on Hegelian idealism, where the value of art lay in its providing an historical record of the transcendental "Idea," "Spirit," or "Consciousness," as it came to be articulated in material form. This process was not linear but discontinuous, full of failures and regressions as people struggled to shape their world, while the mysteriously self-aware idea "pushes on, seeks, divines, and produces ... without attaining absolute satisfaction and therefore without repose." ${ }^{54}$ Fenollosa argued for a geographical relocation of Hegel's philosophy and combined it with the Japanese aestheticization of incompleteness: the idea would no longer enjoy "Teutonic fulfillment." 55

Okakura Kakuzō, who assisted Fenollosa in collecting Japanese antiquities for public collections, took headship of the Tokyo Fine Arts Academy in 1890 on a traditionalist ethos that successfully overturned earlier government policy to promulgate Yōga (Western art). Okakura succeeded his mentor as curator of Asian art at the Boston Museum of Fine Arts in 1911 and much of the intellectual energy of his career was motivated by this Asiatic Hegelianism, emphasizing the importance of human striving with materials even though the results may be imperfect and their decay unavoidable. Lecturing in Boston on "Nature in East Asiatic Painting" (1911), he stated that "what is important is the joy of life coursing through these forms and striving for higher achievements." ${ }^{156}$ And earlier, in The Ideals of the East (1903), he maintained that the inferred meanings and mysteries of haiku, Nō, and sumie all "held steadily to the Oriental Romantistic [sic] ideal . . . the expression of the Spirit as the highest achievement in art. $^{\prime \prime 7}$

Other thinkers at the time were fascinated by this philosophical fusion: Mori Ōgai wrote Japanese translations and commentaries on German idealism, while Ōnishi Hajime formulated a Japano-Christian Hegelianism as an attack upon Buddhism and Shintō. ${ }^{58}$ But idealism was rejected by many Japanese scholars as an unwelcome foreign imposition. The novelist and playwright Tsubouchi Shōyō, for example, quarreled publicly with Ōgai and Ōnishi. ${ }^{59}$ Shōyō armed himself with Eugène Véron's anti-Platonic thesis, L'Esthétique (1878), which adhered to the strict dualist interpretation of Plato: "human intelligence is inert" in the face of unattainable ideals, and 
Plato's disregard for materiality "logically results in the negation of all expression, life, and progress" from art and "reduces [the artist] to ... a mere copyist." Véron's interrogation of Plato-"Have you received the power and peculiar privilege to enter the abstract world of celestial metaphysics, from which everyone else in excluded?"-ignored the materialist-idealist dynamic that underlay Plato's mature philosophy. ${ }^{60}$ When filtered through Shōyō's "What is Beauty?" (1886), which excoriated the "empty theory of a certain figure" - his former teacher Fenollosa-now "revered... as if he were a god," the results were similar. Shōyō lampooned the aspiration to "imitate formless things [and] formless spirits." He favored Japanese traditions, like haiku, that focus on objects and experiences to distil "the essence of the situation." These essences, however, were "mysterious," aspiring to capture "things that cannot exist and cannot generally be seen in reality," which differed little from idealism even in the moment of rejecting it. ${ }^{61}$ According to Marra, Shōyō had failed "to properly interpret Fenollosa's notion of 'idea' (myōsō) in the Platonic sense of 'ideal' and the Hegelian sense of Idee," all indicating transcendent content not in its pure state but when embodied in material and experienced by the senses. ${ }^{62}$

Writing nearly a century later in "The Logic of Passional Surplus" (1972), the philosopher Kusanagi Masao likewise brought Japanese and Western aesthetics into elegant alignment while insisting paradoxically on their irreconcilableness. He was explaining the power of yojōbi, that uncertain feeling caused by the empty areas of a painting or the pauses of a poem: "since human beings live only a finite actual existence ... transcendence, when it appears, can only be read each time instantaneously within historical time... This means that [with art] you have fragmentariness and incompletion." Kusanagi aligned this with "the philosophy of impermanence" of Buddhist and Shintō aesthetics and contended that Western philosophers had only recently awoken to it, citing Karl Jaspers' update of Hegelian idealism (Philosophy, 1932) as an example. ${ }^{63}$ For Jaspers, the finite intellect and lifespan of humans meant that transcendence could be glimpsed only "within the limits of border situations," as fragmentary "traces" or "ciphers" that are experienced in passing, often anxiously and sadly. But this melancholic striving was authentic "Existenz": in the words of Jaspers, "the world is not self-sustaining but perishing all the time," consequently "transcending is an otherwise irremediable disquiet about the impermanence of all existence." ${ }^{64}$

Jaspers' ideas echoed Arthur Schopenhauer's in The World as Will and Representation $(1818,1844)$, which presented the dynamic aspects of Plato's idealism from the viewpoint of a person experiencing it. Imprisoned in the world of "will," of everyday striving and frustration, people glimpsed transcendence only in fragments: "In this state pure knowing comes to us ... to deliver us from willing and its stress. We follow, yet only for a few 
moments; willing, desire, the recollection of our own personal aims, always tears us anew from peaceful contemplation; but yet again and again the next beautiful environment... entices us away from willing." Transcendence could be experienced, moreover, only when mixed with matter in works of art, corresponding to the "mingled and divided state" of human being itself, and with melancholy acknowledgment that the moment must pass. ${ }^{65}$ Kusanagi referred also to Joseph Gartner, Dagobert Frey, and Herbert von Einem, who explored the unfinished works and sketches of Michelangelo, Rembrandt, and Rodin, but concluded that Westerners saw the incomplete as simply incomplete, an abandoned failure or at best preparatory sketch, while for the Japanese incompletion had always been the starting point-an "existential basis" —and the goal: "We can call it the completeness of incompleteness," where the ideal and its manifestation as a fragment are "tied together in a chain of necessity." For Kusanagi, this was quintessentially Japanese. ${ }^{66}$ But Schopenhauer too saw the preparatory sketch as full of a vibrancy and yearning that was seldom matched by the finished painting, and believed that it pointed more powerfully to ideals precisely because it was incomplete. The same went for the unresolved poetic metaphor or the rough sculpture maquette. $^{67}$

Attempts to erect barriers between Japanese and Western aesthetics are often nourished by the hard-line interpretation of idealism that ignores its dynamic engagement with materiality. Consequently, it is unsurprising when they fail to convince.

\section{Conclusion}

We have used Ise and the sengū to reconsider the relationship between Japanese and Western aesthetics. Recent interpretations seem locked into one of two paths: first, the qualities of repetition and perishability are seen in relation to traditional Japanese aesthetics indicating the frailty of earthly things; second, these same qualities are seen in terms of the ostensible emptiness and reproducibility of all culture and linked to post-structuralism. Regardless of the path taken, it is almost invariably contrasted with "western-only" philosophical idealism, understood as the pursuit of changeless, eternal values: "in Japan it is the form that counts. Not form in the Platonic sense of some antecedent pattern beyond the world of change, but form as concretely embodied in a finite, impermanent building." ${ }^{\prime \prime}$ This represents an unsound reading of idealism that hinders discussion of similarities between aesthetic cultures. Many idealists admitted partial and flawed realization of ideals in the material world as part of a recurring, aspirational process. This is a dynamic idealism that is not only compatible with incompleteness, but requires incompleteness in order to be humanized. Clearly this is known among some Japanese and Western thinkers, yet it is usually suppressed under a more established discourse fixated on 
asserting difference. Unique as Ise and the sengū are, a less monolithic reading of Western idealism in relation to the Japanese aesthetic of incompleteness suggests that they speak to something common in the way people, faced with the loss of things that are important to them, have tried to articulate their ideals not against time but within its flow: "Time," Schopenhauer concluded, "is merely the spread-out and piecemeal view that an individual has of the Ideas... Plato says that time is the moving image of eternity." 69

\section{Acknowledgements}

I thank Kumiko Tsuji for Japanese language assistance and my anonymous reviewers for their invaluable criticisms and recommendations.

Notes

1 - Formatting note: Japanese name order of surname-forename is observed throughout; certain figures are popularly known by their forenames or pen names.

2 - James Tartaglia, "Rorty's Thesis of the Cultural Specificity of Philosophy," Philosophy East and West 64, no. 4 (2014), 1018-1038, quotations 1030-1031.

3 - Cassandra Adams, "Japan's Ise Shrine and Its Thirteen-Hundred-YearOld Reconstruction Tradition," Journal of Architectural Education 52, no. 1 (1998), 49-60; Robert S. Ellwood, "Harvest and Renewal at the Grand Shrine of Ise," Numen: International Review for the History of Religion 15, no. 1 (1968), 165-190; Mark Teeuwen, "Early Ise and the Origin of the Sengū system," (presented at "Sengu of the Ise Shrine: Rituals, Myths and Politics", SOAS Centre for the Study of Japanese Religions, London, November 22, 2013).

4 - The "basic, metaphysical reason" for this paradigm is the assumption that the west favors "stillness ... changelessness ... [and] an independent, unchanging ultimate reality," which ostensibly is traceable to Plato's idealism and contrary to the eastern metaphysic of materiality and process: a "disjunction between transcendence and immanence." (Fan Meijun and Wang Zhihe, "Toward a Complementary Consciousness and Mutual Flourishing of Chinese and Western Philosophers: The Contributions of Process Philosophers," Ming Dong Gu and Jianping Guo, "How Can We Cross the Intellectual Divide between East and West?"; both in Philosophy East and West 65, no. 1 [2015], 276-297 [quotations 279-280] and 298-315 [quotations 299, 301-302] respectively). 
5 - Michael Marra, ed., Modern Japanese Aesthetics: A Reader (Honolulu: University of Hawai'i Press, 2002), quotation 9; Michael Marra, ed., A History of Modern Japanese Aesthetics (Honolulu: University of Hawai'i Press, 2001), 2-7.

6 - Otabe Tanehisa, "Representations of 'Japaneseness' in Modern Japanese Aesthetics: An Introduction to the Critique of Comparative Reason," in Japanese Hermeneutics: Current Debates on Aesthetics and Interpretation, ed. Michael Marra (Honolulu: University of Hawai'i Press, 2002), 153-162, quotation 162.

7 - Paul Duro, "Why Imitation, and Why Global?," Art History 37, no. 4 (2014), 607-626, especially 612-618, 625-626.

8 - Karatani Kōjin, "Uses of Aesthetics: After Orientalism," trans. Kohso Sabu, Boundary 2 25, no. 2 (1998), 145-160; Duro, "Why Imitation," quotation 614.

9 - Bruno Taut, Houses and People of Japan (Tokyo: Sanseido, 1937), 138-145, quotations 139, 143-144; Jonathan M. Reynolds, "Ise Shrine and a Modernist Construction of Japanese Tradition," The Art Bulletin 83, no. 2 (2001), 316-341, especially 317-322; Sandra Kaji-O'Grady, "Authentic Japanese architecture after Bruno Taut: the problem of eclecticism," Fabrications 11, no. 2 (2001), 1-12.

10 - Reynolds, "Ise Shrine," 325-336, quotation 316.

11 - Tange Kenzō, "Ise: Prototype of Japanese Architecture," in Tange Kenzō and Kawazoe Noboru, Ise: Prototype of Japanese Architecture, trans. Eric Klestadt and John Bester (Cambridge, Mass.: MIT Press, 1965), 13-52, quotation 16; Kawazoe Noboru, "The Ise Shrine and Its Cultural Context," in Tange and Kawazoe, Ise: Prototype, 165-206, quotation 202; Kawazoe Noboru, "The Ise Shrine," Japan Quarterly 9, no. 3 (1962), 285-292, quotation 285-286, see also 290; William Coaldrake, Architecture and Authority in Japan (London: Routledge, 1996), 16-51.

12 - Piet Mondrian, "Plastic Art and Pure Plastic Art," in Modern Artists on Art, ed. Robert L. Herbert (New York: Dover Publications, 2000), 152-166, quotations 152, 154.

13 - See my Le Corbusier and the Concept of Self (New Haven and London: Yale University Press, 2003), 11-18, 208, n. 5, 210 ns. 29, 30, 32.

14 - Kawazoe, "Cultural Context," 202.

15 - Roland Barthes, Empire of Signs (1970), trans. Richard Howard (New York: Hill and Wang, 1982). For examples on the emptiness of Japanese cuisine, manners, sport, theatre, railways and palaces, see 11-26, 30-40, 48-68, 107-110. 
16 - Barthes, Empire, 69-84, quotations 69, 74, 76, 79, 82-83.

17 - Barthes, Empire, 43-47, quotations 45-46.

18 - Barthes, Empire, 55.

19 - Hirata Toshihiro, "The Pliant Philosophy of Sakabe Megumi" (1990), trans. Marra, in Marra, History, 211-222; Marra, History, 14-17.

20 - Sakabe Megumi, "Mask and Shadow in Japanese Culture: Implicit Ontology in Japanese Thought" (1982), trans. Marra, in Marra, Reader, 242-251, quotations 244-247; Barthes, Empire, 99-102.

21 - Sakabe Megumi, "Modoki: The Mimetic Tradition in Japan" (1985), trans. Marra, in Marra, Reader, 251-262, quotations 253, 258; Sakabe, "Mask and Shadow," 247-248.

22 - Isozaki Arata, Japan-ness in Architecture (2006), trans. Kohso Sabu (Cambridge, Mass. and London: MIT Press, 2011), x-xii, 119-169, quotations 130-131, 138, 141, 151, 168-169.

23 - Isozaki, Japan-ness, 132, 156-157.

24 - Isozaki, Japan-ness, 142, 147.

25 - Isozaki, Japan-ness, 5, 59-80, 147-151.

26 - Tange, "Ise: Prototype," 16, 26, 30-33, 40-42, quotation 30-33.

27 - Adrian Snodgrass, "Thinking Through the Gap: The Space of Japanese Architecture," Architectural Theory Review 16, no. 2 (2011), 136-156, especially 138-144, 149-150; Günter Nitschke, "'Ma': The Japanese Sense of 'Place' in Old and New Architecture and Planning," Architectural Design 36, no. 3 (1966), 116-156, especially $117,154$.

28 - Isozaki, Japan-ness, 93-97 and 327-328, n. 16, quotation 145; Isozaki Arata, "Ma - Space/Time in Japan" (1981), trans. Amiya Yoshiko et al., in Ken Tadashi Oshima, Arata Isozaki (London and New York: Phaidon Press, 2009), 156-161, 172-175.

29 - Saitō Yuriko, "The Japanese Aesthetics of Imperfection and Insufficiency," Journal of Aesthetics and Art Criticism 55, no. 4 (1997), 377-385, quotations 377, 380; "Japanese Aesthetics of Packaging," Journal of Aesthetics and Art Criticism 57, no. 2 (1999), 257-265, quotation 259; "The Japanese Appreciation of Nature," British Journal of Aesthetics 25, no. 3 (1985), 239-251, especially 245-249 on transience.

30 - Motoori Norinaga, "The Logic of the Priest Kenkō" (ca. 1793-1801), in The Poetics of Motoori Norinaga: A Hermeneutical Journey, ed. and trans. Michael Marra (University of Hawai'i Press, Honolulu, 2007), 
129-130; Saitō, "Imperfection and Insufficiency," 380; "Appreciation of Nature," 243-244.

31 - Motoori Norinaga, "On Mono no Aware" (1763 and various), trans. Marra, in Marra, Motoori Norinaga, 172-194, especially 172-185, quotation 184; see also Michael Marra, "Motoori Norinaga's Poetics," in Marra, Motoori Norinaga, 3-28, especially 20-22, and Mark Meli, "Motoori Norinaga's Hermeneutic of Mono no Aware: The Link between Ideal and Tradition," in Marra, Japanese Hermeneutics, 60-75.

32 - Yoshida Kenkō, Essays in Idleness (ca. 1330), in Yoshida Kenkō and Kamo no Chōmei, Essays in Idleness and Hōjōki, trans. Meredith McKinney (London: Penguin, 2013), 21-140, especially 30-31, 87-88, quotations 24, 31, 58, 61.

33 - Ōnishi Yoshinori, "Aware" (1960), trans. Marra, in Marra, Reader, 122-140, quotations 123, 137. For conflicting appraisals of Ōnishi's "method" see Takeuchi Toshio, "Ohnishi's Aesthetics as a Japanese System," Journal of Aesthetics and Art Criticism 24, no. 1 (1965), 7-18, and Ueda Makoto, "Yūgen and Erhabene: Ōnishi Yoshinori's Attempt to Synthesize Japanese and Western Aesthetics," in Culture and Identity: Japanese Intellectuals During the Interwar Years, ed. J. Thomas Rimer (Princeton: Princeton University Press, 1990), 282-299, especially 297-298.

34 - Wm. Theodore de Bary, "The Vocabulary of Japanese Aesthetics, I, II, III" (1958), in Japanese Aesthetics and Culture: A Reader, ed. Nancy G. Hume (Albany: SUNY Press, 1995), 43-76, especially 43-47, 50-55, 69-72, quotation 47.

35 - Donald Keene, "Japanese Aesthetics" (1988), in Hume, Japanese Aesthetics, 27-41, quotation 29.

36 - Meli, "Motoori Norinaga," quotation 60; also Keene, "Japanese Aesthetics," 31 and De Bary, "Vocabulary," 55.

37 - Dominic Mclver Lopes, "Shikinen Sengu and the Ontology of Architecture in Japan," Journal of Aesthetics and Art Criticism 65, no. 1 (2007), 77-84, quotations 81.

38 - Rafael de Clercq, "Lopes on the Ontology of Japanese Shrines," Journal of Aesthetics and Art Criticism 66, no. 2 (2008), 193-194.

39 - Jeffrey Perl, "Regarding Change at Ise Jingu," Common Knowledge 14, no. 2 (2008), 208-220, especially 208-212, quotations 215, 218-219.

40 - Wayne Anderson, "Moving Constants - In The West: A Response to 'Change at Ise Jingu'," Common Knowledge 14, no. 3 (2008), 384-395, quotations 385-386, 391-392, 394. 
41 - Rosalind Krauss, "The Originality of the Avant-Garde" (1981), in Krauss, The Originality of the Avant-Garde and Other Modernist Myths (Cambridge, Mass. and London: MIT Press, 1986), 151-170; Albert Elsen, "On the Question of Originality: A Letter," October 20 (1982), 107-109.

42 - Robert Wicks, "Architectural Restoration: Resurrection of Replication?," British Journal of Aesthetics 34, no. 2 (1994), 163-169.

43 - G. E. Moore, "The Refutation of Idealism," Mind 12, no. 48 (1903), 433-453, especially 436, 445, 448, 451.

44 - M. F. Burnyeat, "Idealism and Greek Philosophy: What Descartes Saw and Berkeley Missed," The Philosophical Review 91, no. 1 (1982), 3-40, especially 3, 8, 13-14, 20-25, 28-30, 37-40.

45 - Jeremy Dunham, lain Hamilton Grant and Sean Watson, Idealism: The History of a Philosophy (London: Routledge, 2014), especially 8, 21-26, 31-32, quotations 3-4, 6-8, 23, 201-208; Vasilis Politis, "Anti-Realist Interpretations of Plato: Paul Natorp," International Journal of Philosophical Studies 9, no. 1 (2001), 47-62, especially 51-55, 59-61.

46 - Gustavus George Zerffi, "The Historical Development of Idealism and Realism," Transactions of the Royal Historical Society 6 (1877), 304-323, especially 304-312, quotation 309; C. M. Bakewell, "Idealism and Realism," The Philosophical Review 18, no. 5 (1909), 503-513, quotation 508; Gustav E. Mueller, "Plato's Dialectical Idealism," The Monist 45, no. 2 (1935), 199-219, quotations 203, 207, 210.

47 - Plato, The Republic, trans. Desmond Lee (London: Penguin, 1987), 206-217, 306-325, 421-435.

48 - Plato, The Symposium, trans. Christopher Gill (London: Penguin, 1999), 32-50, quotations 39, 49-50.

49 - Plato, Phaedrus, trans. Christopher Rowe (London: Penguin, 2005), 28-38; Plato, Phaedo, trans. Hugh Tredennick and Harold Trannant, in Plato, The Last Days of Socrates (London: Penguin, 2003), 97-199, especially 146-154, 196-197, quotation 153.

50 - Philip Sherrard, "Art and Originality," Studies in Comparative Religion 14, nos. 3-4 (1980), 1-9, quotations 1, 7, www.studiesin comparativereligion.com, accessed December 12, 2016.

51 - Omid Tofighian, "Rethinking Plato's Theory of Art: Aesthetics and the Timaeus," Literature and Aesthetics 19, no. 2 (2009), 25-40, citation 27, quotations 35, 37, 39.

52 - Mueller, "Plato's Dialectical Idealism," 214-215, 219. 
53 - Zerffi, "Idealism and Realism," 313-316; see also the idealist allusions in George Santayana's account of Lucretius. (Three Philosophical Poets: Lucretius, Dante, and Goethe [1910] [Cambridge, Mass.: Harvard University Press, 1922], 42-44).

54 - G.W.F. Hegel, Aesthetics: Lectures on Fine Art, vol. II (1820s), trans. T. M. Knox (Oxford: Oxford University Press, 1975), 631-697, quotation 646-647, and Lectures on the Philosophy of World History (1837), trans. H. B. Nisbet (Cambridge: Cambridge University Press, 1975), 30-33, 44-46, 52-63; Michael Podro, The Critical Historians of Art (New Haven and London: Yale University Press, 1982), 17, 27.

55 - Marra, Reader, 65.

56 - Marra, Reader, citation 71.

57 - F. G. Notehelfer, "On Idealism and Realism in the Thought of Okakura Tenshin," Journal of Japanese Studies 16, no. 2 (1990), 309-355, citation 333. On this reformulation of Hegel for Japan: Karatani Kōjin, "Japan as Art Museum: Okakura Tenshin and Fenollosa" (1994), in Marra, History, 43-52; J. Thomas Rimer, "Hegel in Tokyo: Ernest Fenollosa and His 1882 Lecture on the Truth in Art," in Marra, Japanese Hermeneutics, 97-108; Ueda, "Yūgen and Erhabene," 283-286.

58 - Ōnishi Hajime, "There Is No Religion in Waka" (1887), trans. Marra, in Marra, Reader, 83-92, also 8, 79-83. See also Watanabe Kazuyasu, "Ōnishi Hajime: Criticism and Aesthetics" (1986), Bruno Lewin, "Mori Ōgai and German Aesthetics" (1989); both in Marra, History, 95-105 and 68-92 respectively.

59 - Marra, Reader, 8; Marra, History, 9-12.

60 - Marra, Reader, 38-48, quotation 43, citations from W. H. Armstrong's 1879 translation of Véron's Aesthetics, 44-45.

61 - Tsubouchi Shōyō, "What is Beauty?" (1886), trans. Marra, in Marra, Reader, 48-64, quotations 49, 54-56.

62 - Marra, History, 9; see also Tamio Kaneda, "Fenollosa and Tsubouchi Shōyō," trans. Marra, in Marra, History, 53-67, especially 59-65 on the similarities between Shōyō's aesthetic and idealism.

63 - Kusanagi Masao, "The Logic of Passional Surplus" (1972), trans. Marra, in Marra, Reader, 148-167, quotation 156, see also 153, 157.

64 - Marra, Reader, 141-148, quotation 147, citation from E. B. Ashton's 1969 translation of Jasper's Philosophy, 146, n. 17. 
65 - Arthur Schopenhauer, The World as Will and Representation, vol. I (1818, 1844), trans. E.F.J. Payne (New York; Dover Publications, 1969), 169-178, 181-187, 195-218, 230-233, quotation 250.

66 - Kusanagi, "Passional Surplus," 156-163, quotations 158-159, 163.

67 - Arthur Schopenhauer, "Supplements to the Third Book" of The World as Will and Representation, trans. R. B. Haldane and J. Kemp, in Philosophies of Art and Beauty: Selected Readings in Aesthetics from Plato to Heidegger, eds. Albert Hofstadter and Richard Kuhns (Chicago: University of Chicago Press, 1976), 452-456, quotation 454.

68 - Graham Parkes, "Ways of Japanese Thinking" (1993), in Hume, Japanese Aesthetics, 77-108, quotation 83; see also Florian Coulmas, "Eternal Change at the Grand Shrine of Ise," Japan Quarterly 41, no. 1 (1994), 36-43.

69 - Schopenhauer, Will and Representation, 176. 